\section{ヒトカルシトニンのアミロイド様線維形成機構とその阻害効 果の解析}

Analyses of amyloid fibrillation mechanism and its inhibition

effect of $\mathrm{hCT}$ as studied by ${ }^{13} \mathrm{C}$ solid-state NMR and TEM

Hikari Itoh-Watanabe ${ }^{1}$, Miya Kamihira-Ishijima ${ }^{2}$, Izuru Kawamura ${ }^{1}$, Masashi Kondoh ${ }^{3}$, Michio $\mathrm{Sato}^{3}$, Masamichi Nakakoshi ${ }^{3}$, Akira Naito ${ }^{1}$ (' ${ }^{1}$ Graduate School of Engineering, Yokohama National University, Yokohama, ${ }^{2}$ Institute of Multidisciplinary Research, Tohoku University, Sendai, Japan., Instrumental Analysis Center, Yokohama National University, Yokohama, Japan.)

Human calcitonin (hCT) known as peptide thyroid hormone, plays a central role in calcium-phosphorus metabolism. HCT forms amyloid fibri in concentrated aqueous solution. We have shown that the fibrillation mechanism of hCT can be analyzed using a two-step autocatalytic reaction mechanism. In this study, we particularly investigated the early process in the fibril formation in HEPES solution. The morphology of the early process was examined by means of TEM, and turned out that the fibril formation in HEPES is much slower than that in acetic acid solution. It was nated that intermediate was seen in the early process. This observation clearly supports that hCT fibril takes a two-step autocatalytic reaction mechanism.

3P068

$$
\begin{aligned}
& \beta_{2} \text { ミクログロブリンのアミロイド幹形成領域のスキャン } \\
& \text { 探索 }
\end{aligned}
$$$$
\text { Scanning survey for amyloid-stem-forming region of } \beta_{2^{-}}
$$$$
\text { microglobulin }
$$

Hisayuki Morii ${ }^{1}$, Takashi Shimizu ${ }^{1}$, Masayuki $\operatorname{Nara}^{2}\left({ }^{1}\right.$ National Institute of Advanced Industrial Science and Technology (AIST), ${ }^{2}$ College of Liberal Arts and Sciences, Tokyo Medical and Dental University)

Amyloid formation of $\beta_{2}$-microglobulin is responsible for dialysis-related amyloidosis. The most relevant region to amyloidogenicity is considered to be (20-41). Structural models of the amyloid have been reported using isotope-labeling IR and solid-state NMR for K3-peptide that corresponds to (20-41). Herein, we developed 2-dimensional scanning method in order to identify a pair of $\beta$-strands that form the amyloid-stem, a cross- $\beta$ structure in fibrils. The survey was carried out with the peptides consisting of systematically selected two 6-residue sequences and a designed turninducing linker, Asp- $\left(\mathrm{D}_{\mathrm{D}}-\mathrm{Ala}\right)$. The specific residue-residue interactions between thus-identified two $\beta$-strands in K3-peptide region were found to have an important role for amyloidogenicity.

\section{P069 \\ ヒトカルシトニンの酸性膜存在下でのアミロイド線維形成機 構の解明}

\section{Amyloid-like fibrillization and the structure of human} calcitonin in the presence of acidic lipids

Akira Asano ${ }^{1}$, Yuki Abe ${ }^{1}$, Ken Takeuchi ${ }^{1}$, Miya Kamihira-Ishijima ${ }^{2}$, Hikari Itoh-Watanabe $^{1}$, Izuru Kawamura ${ }^{1}$, Ayyalusamy Ramamoorthy ${ }^{3}$, Akira Naito ${ }^{1}\left({ }^{1}\right.$ Graduate School of Engineering, Yokohama National University, ${ }^{2}$ Graduate School of Life Science, University of Hyogo, ${ }^{3}$ Biophysics and Department of Chemistry, University of Michigan)

Human calcitonin (hCT) is a 32-residue peptide hormone, involves in bone calcium metabolism and known as amyloid peptide. However, the detailed fibrillization mechanism is not well understood. In this study, the structure and fibrillation kinetics of hCT in solution containing neutral and acidic phospholipids (bicelles and micelles) were observed using NMR and UVVis spectroscopies. The fibrillation kinetics was revealed using a two-step autocatalytic reaction model composed of fibril nucleation $\left(\mathrm{k}_{1}\right)$ and fibril elongation reaction $\left(\mathrm{k}_{2}\right)$. In the presence of lipids, the first reaction was accelerated but the second reaction was decelerated. The surface condensation effect and the electrostatic interaction between hCT and lipid may play a role in fibril formation.

\section{P070}

\section{インスリン B 鎖に見られる多様なアミロイド線維前駆中間 体の観察}

Observation of various types of amyloid prefibrillar

intermediates of insulin B chain

Shoko Tsuhara, Eri Chatani (Grad.Sch.of Sci.,Kobe.Univ)

Amyloid fibrils are protein aggregates associated with many diseases. To elucidate detailed mechanism of amyloid fibril formation, we have investigated the fibrillation process of insulin B chain. Immediately after dissolving this peptide in buffer solution, significant ThT fluorescence intensity was observed, and the needle-like mature fibrils were formed subsequently without any lag phase, suggesting the formation of a prefibrillar intermediate at the initial stage. Interestingly, different types of prefibrillar intermediates in terms of cross- $\beta$ content and morphology were observed dependent of $\mathrm{pH}$, and these species further developed to form different mature fibrils, implying that these intermediates play a role as nuclei determining final amyloid structures.

3P071

\section{金属イオン配位によるインスリンアミロイド線維の多形誘導} 効果

Polymorphism of insulin amyloid fibrils induced by the coordination of metal ions

Misaki Yokoyama, Yoshito Huruie, Motonari Tubaki, Hiroshi Hori, Eri Tyatani (Grad.Sch.of Sci.,Kobe Univ)

Amyloid fibrils are protein assemblies with a potential application as a new material in the field of nanotechnology. To control physicochemical properties of amyloid fibrils, polymorphism, a feature with which a variety of fibril structures are formed even from one protein sequence, may be useful. In this study, we have attempted to induce polymorphic fibrils of insulin by altering initial association state with zinc ions. As a result, we could obtain fibrils both in the presence and absence of zinc ions, and the amyloid fibrils formed with zinc ions had stronger tolerance for $\mathrm{pH}$ induced dissociation than those formed without zinc. This result indicates that metal ion is an effective factor to manifest polymorphism of insulin fibrils.

\section{P072}

Exploring roles of water molecules on amyloid fibrillation by salt effects and Near Infrared spectroscopy

Yuuki Masuda ${ }^{1}$, Yutaro Tsuchisaka ${ }^{2}$, Roumiana Tsenkova ${ }^{2}$, Eri Chatani ${ }^{1}$ $\left({ }^{1}\right.$ Graduate school of science, Kobe University, ${ }^{2}$ Graduate school of Agricultural Science, Kobe University)

To clarify mechanisms of the formation of amyloid fibrils, we have performed systematic analysis of salt effects and near infrared (NIR) spectroscopic measurements for the fibrillation of insulin. When nucleation and extension rates were measured in the presence of various types and concentrations of salts, both of acceleration and deceleration were observed in a concentration-dependent manner for all salts, and especially, the deceleration observed at high concentrations followed Hofmeister series. Furthermore, we could find some characteristic changes in water structures during the fibrillation by time-resolved NIR spectroscopy. From these results, it has been suggested that specific states of hydrating and bulk water contribute to efficient fibril formation. 